\title{
NITROBLUE TETRAZOLIUM TEST AS AN ASSAY OF NEUTROPHIL FUNCTION IN DIABETES MELLITUS
}

\author{
S. Srivani' ${ }^{1}$ A. P. Jonathan Arnold², Usha Varadarajan ${ }^{3}$
}

${ }_{1}^{1}$ Associate Professor, Department of Pathology, Sri Manakula Vinayagar Medical College and Hospital, Pondicherry, India. ${ }^{2}$ Associate Professor, Department of Pathology, Sri Venkateshwaraa Medical College Hospital and Research Centre, Pondicherry, India. ${ }^{3}$ Retired Professor and HOD, Department of Haematology, MMC, Chennai, Tamilnadu, India.

\begin{tabular}{l}
\hline ABSTRACT \\
BACKGROUND \\
Neutrophil functions can be assessed by various methods like flow cytometry, spectrophotometry, chemotaxis assays and superoxide \\
assays which require expertise and expense, and thus limited to research centres unlike the Nitroblue Tetrazolium [NBT] Test. \\
NADPH oxidase in neutrophils converts NBT dye to a blue black deposit [Formazan], which can be visualized and scored, and the \\
scores are directly related to the quantity of NADPH oxidase in activated state. We attempt to describe the NBT test and measuring \\
methods, its relation to neutrophil bactericidal function, and to compare its values in neutrophil dysfunctional states like diabetes \\
with those without it especially when neutrophils are stimulated by bacterial infection.
\end{tabular}

\section{METHODS}

The study included 127 subjects divided into 4 categories namely, non-diabetics without bacterial infection (ND), non-diabetics with bacterial infection (NDI), diabetics without bacterial infection (D), and diabetics with bacterial infection (DI) on whom fasting blood sugar [FBS], bacteriological tests and NBT staining of buffy coat neutrophils was done, smears made and NBT values estimated.

\section{RESULTS}

The mean NBT values based on Classic System [CS] were: $21.8 \%$ (ND), 76.5\% (NDI), 32.7\% (D) and 63.4\% (DI), while the same by Grading System [GS] were 82 (ND), 228.5 (NDI), 117.2 (D) and 198.8 (DI). Non-diabetics and diabetics with infection had significantly higher NBT values than non-diabetics and diabetics without bacterial infection respectively. D category had higher NBT values than that of ND category, while the NBT values of DI category did not reach the high mean NBT values of non-diabetics with infection.

\section{CONCLUSIONS}

Both classic and grading systems showed comparable results. Higher NBT values obtained in those exposed to bacterial infection agree well with the concomitant increased bactericidal activity of neutrophils. Higher baseline NBT values of non-infected diabetics could be related to the persistent activated state of neutrophils seen in diabetics due to advanced glycation end products. Finally, 'burn out' of neutrophils, which respond inadequately to infectious stimuli, may be the reason for lower NBT values of infected diabetics when compared with infected non-diabetics.

\section{KEY WORDS}

Nitroblue Tetrazolium [NBT] Test, Diabetes Mellitus, Neutrophil Bactericidal Activity, NADPH Oxidase, Bacterial Infection

HOW TO CITE THIS ARTICLE: Srivani S, Arnold APJ, Varadarajan U. Nitroblue tetrazolium test as an assay of neutrophil function in diabetes mellitus. J. Evolution Med. Dent. Sci. 2019;8(25):2016-2022, DOI: 10.14260/jemds/2019/444

\section{BACKGROUND}

The neutrophils among many other functions protect the host against pyogenic infections. The cellular events in acute inflammation include mobilization of neutrophils from marrow stores, adhesion and extravasation of the leucocytes, chemotaxis, leukocyte activation, phagocytosis, with ultimate killing and degradation of the organisms.1,2 Bactericidal mechanisms of neutrophils include oxidative and nonoxidative mechanisms of which the former is more important. Phagocytosis stimulates a burst in $\mathrm{O}_{2}$ consumption, glycogenolysis, increased glucose oxidation via HMP shunt along with the production and release [respiratory burst] of reactive oxygen metabolites by the granules of activated

'Financial or Other Competing Interest': None.

Submission 19-05-2019, Peer Review 10-06-2019,

Acceptance 17-06-2019, Published 24-06-2019.

Corresponding Author:

Dr. A. P. Jonathan Arnold,

Department of Pathology,

Sri Venkateshwaraa Medical College

Hospital and Research Centre,

No. 13A, Pondy-Villupuram Main Road,

Ariyur-605102, Pondicherry, India.

E-mail: jonathanarnold79@gmail.com

DOI: $10.14260 /$ jemds $/ 2019 / 444$ neutrophils. The reactive oxygen species include superoxide anion $\left(\mathrm{O}_{2}^{-}\right)$, hydrogen peroxide $\left(\mathrm{H}_{2} \mathrm{O}_{2}\right)$, hydroxyl radicals $(\mathrm{OH} \cdot)$, hypochlorous acid $(\mathrm{HOCl})$ and singlet oxygen and are important in bactericidal action. These reactive intermediates are generated by enzymes including NADPH oxidase, located on the plasma membrane and the fundamental chemical reactions are mentioned below. ${ }^{3.4}$

\section{Synthesis of Reactive Oxygen Intermediates}

\begin{tabular}{|c|c|c|}
\hline $\mathrm{NADPH}+2 \mathrm{O}_{2}$ & NADPH oxidase & $\mathrm{NADP}+2 \mathrm{O}_{2}^{-}+\mathrm{H}^{+}$ \\
\hline $\mathrm{O}_{2}^{-}+\mathrm{O}_{2}^{-}+2 \mathrm{H}^{+}$ & Superoxide dismutase & $\mathrm{H}_{2} \mathrm{O}_{2}+\mathrm{O}_{2}$ \\
\hline $\mathrm{H}_{2} \mathrm{O}_{2}+\mathrm{Cl}^{-}$ & Myeloperoxidase & $\mathrm{H}_{2} \mathrm{O}+\mathrm{OCl}^{-}$ \\
\hline
\end{tabular}

Many tests are available to assess neutrophil functions which include flow cytometry, spectrophotometric assays, chemotaxis assays, superoxide assays and immunoblotting 1 which though accurate require expertise and monetary consideration while the Nitroblue Tetrazolium [NBT] test is inexpensive and technically less demanding. 
Nitroblue tetrazolium is a colorless or yellow dye [figure $1 \mathrm{a}]$, which can penetrate the neutrophil cell membrane. If neutrophils are activated [during bacterial infections], NADPH oxidase is in active form and converts the dye in the phagolysosome into blue black deposits called as formazan which can be observed under the microscope. In unstimulated conditions (like non-infectious states), most of the NADPH oxidase is inactive and hence formazan formation on addition of NBT dye is less. ${ }^{5}$

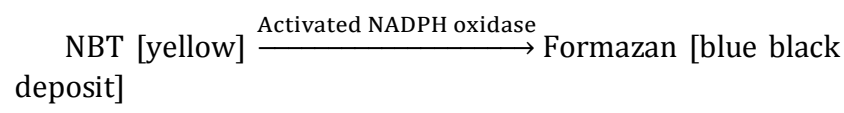

Hence, the formation of formazan is an indirect evidence to the degree of respiratory burst activity of neutrophils.

The origin of NBT test dates back to 1967, when Baehner and Nathan ${ }^{6}$ showed that while a small fraction of the neutrophils of normal subjects could in vitro reduce the NBT dye to formazan precipitate, neutrophils from chronic granulomatous disease (CGD) patients were unable to effect this reaction, thus providing a sensitive diagnostic test for the diagnosis of CGD. Enhanced NBT reduction was reported by Park, Fikrig and Smithwick ${ }^{7}$ [bacterial infection in children], Feigin et al ${ }^{8}$ (in systemic bacterial infections), Anderson et $\mathrm{al}^{9}$ (malaria), Humbert et al10 (new born infants) and in scarlet fever. ${ }^{11}$ McCall et al ${ }^{12}$ conducted NBT test along with other bactericidal indices like oxygen utilization and hexose monophosphate shunt activity. They observed significant elevations in bactericidal indices above that of controls, in all patients with elevated NBT values. Thus, it proved that increased bactericidal capacity of neutrophils was the primary cause of increased NBT reduction.

Some infections are more frequent and or more aggressive in the diabetic host. Apart from secondary host factors in diabetics like delayed wound healing, chronic renal disease, recurring hospitalization with associated risk of hospital acquired infections, diabetic micro \& macro vasculopathy and diabetic neuropathy, 13 there are multiple defects in immunity in diabetes mellitus [DM], which may explain the susceptibility to infection, including among others, defects in several neutrophil functions ${ }^{14-16}$ like adherence, chemotaxis, phagocytosis, bactericidal activity [defect in production of $\mathrm{O}_{2}$ derived free radicals] and antimicrobial function of neutrophil antimicrobial molecules like lactoferrin and lysozyme [which are bound to advanced glycation end products (AGEs) seen in diabetes]. ${ }^{17}$ Also, there is a state of persistent low level activation of the neutrophils by AGEs which is evidenced by an increased concentration of neutrophil elastase, increased activity of neutrophil alkaline phosphatase and an increased rate of neutrophil oxygen consumption among unstimulated neutrophils of patients with diabetes. This hyperexcited state leads to spontaneous activation of the respiratory burst and release of neutrophil granule components that may lead to exhaustion of neutrophils that respond less vigorously when stimulated by an infectious pathogen. ${ }^{18}$ Relatively a few authors have done works using NBT test in diabetes mellitus. Kruszewski et al ${ }^{19}$ studied 44 diabetic patients and found normal range of NBT values in those without infection and significantly higher values in those with bacterial infection. Larijani et $\mathrm{al}^{20}$ in 2007 compared NBT values between type 2 diabetes patients and healthy controls. They found that NBT values were significantly high in diabetics compared to controls. But stimulation (by endotoxin) resulted in inadequate rise of NBT values compared to controls.
The objectives of our study included describing the NBT test, its relation to bactericidal function of neutrophils, its measuring systems, and its values in those with or without diabetes and with or without bacterial infection [to assess the response to infection in the diabetic population].

\section{METHODS}

This prospective study was conducted in the Hematology division of Goschen Institute of Pathology, Madras Medical College [MMC]. The study included 127 subjects divided into 4 categories, the sample size being based on significance level, power of the study and prevalence of diabetes and infection: 31 healthy controls [non-diabetics without bacterial infection (ND)], 31 non-diabetic patients with bacterial infection (NDI), 33 patients with diabetes mellitus (D) but no bacterial infection (asymptomatic infections like UTI excluded by urine culture) and 32 patients of diabetes with bacterial infection (DI). The bacterial infection was confirmed by bacteriological isolation through culture or other relevant tests. The selected diabetic study population had DM for at least 2 years duration, with or without treatment. Patients with subclinical infection, who had completed a full course of antibiotics, those in convalescence, and those with duration of diabetes of $<2$ years were excluded from the study. After obtaining informed consent, and IEC clearance, the clinical details collected included age \& sex, details regarding DM, infection and treatment. The lab investigations included fasting blood sugar ([FBS] normal range: $75-115 \mathrm{mg} / \mathrm{dl}$; in diabetes mellitus: >125 $\mathrm{mg} / \mathrm{dl}$ ), ${ }^{21} \mathrm{WBC}$ counts, bacteriological tests [culture, WIDAL or MSAT] and NBT test.

Reagents required for the NBT test included Solution A [0.2 M Monobasic sodium phosphate (31.2 g $\mathrm{NaH}_{2} \mathrm{PO}_{4} .2 \mathrm{H}_{2} \mathrm{O} /$ Litre)], Solution B [0.2 M Dibasic sodium phosphate (28.3 g $\mathrm{Na}_{2} \mathrm{HPO}_{4} /$ Litre $\left.)\right]$, Deionised water, Nitroblue tetrazolium dye (crystalline grade III, Sigma chemical company) and aqueous safranin $0.5 \%$. To $20 \mathrm{ml}$ of solution A, $80 \mathrm{ml}$ of solution B was added. This solution was dissolved in $100 \mathrm{ml}$ deionised water, forming the working buffer with a final $\mathrm{pH}$ of 7.2. The NBT solution was prepared by dissolving the NBT dye at a concentration of $0.2 \%$ to the working buffer, and stored at $4^{\circ} \mathrm{C} .5$

The method followed in this study was a modification of that of Gordon et al. $5 \mathrm{ml}$ EDTA anticoagulated blood was collected from each subject, transferred to plastic test tubes and centrifuged at $3000 \mathrm{rpm}$ for 8 minutes. The separated buffy coat was transferred using plastic pipettes into separate plastic tubes. Equal amount of NBT solution was added, mixed gently and incubated at $37^{\circ} \mathrm{C}$ for 30 minutes and left at room temperature for 15 minutes [Figure 1]. The mixture was mixed again gently, a drop of which was smeared on a glass slide, dried, heat fixed and counterstained with safranin for 2 minutes that stain the nuclei of leucocytes red. The smears were then washed and left to dry. The slides were examined under oil immersion objective (1000x) and 100 consecutive neutrophils were observed sequentially. Only neutrophils with intact cell membranes were taken for observation. The measurement was done by both the classic system [CS] and grading system [GS]. In the classic system, of the 100 neutrophils examined, the total number of neutrophils exhibiting discrete fine/coarse particulate cytoplasmic distribution of formazan as blue/black granules, in addition to dense deposits of formazan ${ }^{5}$ were counted as NBT positive cells and expressed as percentage [NBT \%]. Those cells which 
showed no formazan deposits were counted as NBT negative [Figure 2]. The number or nature of formazan granules was not taken into consideration. NBT \% in healthy volunteers (Range) in our study was 6-25\%.

In the NBT grading system [GS], Grading of the number and nature of formazan granules in NBT stained neutrophils was attempted similar to that of NAP (Neutrophil alkaline phosphatase) scoring. ${ }^{22}$ An overall score is obtained by assessing the stain intensity in 100 consecutive neutrophils, with each neutrophil graded [Figure 3] on a scale of $0-4$ as follows-

0 - Negative, no granules.

1 - Occasional granules scattered in the cytoplasm.

2 - Moderate number of granules $<25 \%$ of cytoplasm.

3 - Numerous granules occupying $<50 \%$ cytoplasm.

4 - Heavy positivity with numerous coarse granules crowding the cytoplasm, frequently overlying the nucleus, $>50 \%$ of cytoplasm.

The overall possible score ranged between 0 and 400 per 100 cells. The NBT grading score in healthy volunteers in our study: 12-167.

\section{Statistical Analysis}

Statistical analysis was done using SPSS software. The average [Mean value] of NBT scores for each category was calculated using the formula

Mean $=\sum \mathrm{X} \div \mathrm{n}$

Where, $\sum X=$ Sum of all the NBT values in a category; and $n=$ Total number of subjects in each category.

Then Standard deviation was calculated using the formula-

$s=\sqrt{\frac{\sum(X-\bar{X})^{2}}{n-1}}$

Where,

$\mathrm{s}=$ standard deviation of the category

$\sum$ = sum of...

$\mathrm{X}=$ NBT value of each case

$\bar{X}=$ mean NBT value

$\mathrm{n}=$ number of subjects in given category.

Following this, the Standard Error of mean was calculated as:

$$
S E_{\bar{x}}=\frac{S}{\sqrt{n}}
$$

Where

SEx $=$ Standard Error of the Mean

$\mathrm{s}=$ Standard Deviation of the Mean

$\mathrm{n}=$ Number of Observations in the Category

Finally, the mean NBT values of each of the four categories were compared using the $\mathrm{Z}$ test [Table 5 to 8 ]

\section{RESULTS}

The mean NBT \% [Number of NBT positive neutrophils out of 100 neutrophils examined] of the four categories are presented in table 1.
ND category consisted of 17 males and 14 females [31 subjects in total]. The age range of this group was 18 to 41 years, with a median of 20 years. All were healthy with no signs and symptoms of DM or infection. There was no significant difference $(p>0.05)$ in the mean NBT values between the males (20.6\%) and females (23.3\%).

\begin{tabular}{|c|c|c|c|}
\hline Category & $\begin{array}{c}\text { Number } \\
\text { of } \\
\text { Subjects }\end{array}$ & $\begin{array}{c}\text { Mean } \\
\text { NBT \% }\end{array}$ & $\begin{array}{c}\text { NBT Confidence } \\
\text { Interval } \\
\text { (Mean+/-2SE) }\end{array}$ \\
\hline $\begin{array}{c}\text { Non-diabetics without } \\
\text { bacterial infection (ND) }\end{array}$ & 31 & 21.8 & $21.8+/-5$ \\
\hline $\begin{array}{c}\text { Non-diabetics with bacterial } \\
\text { infection (NDI) }\end{array}$ & 31 & 76.5 & $76.5+/-6.4$ \\
\hline $\begin{array}{c}\text { Diabetics without bacterial } \\
\text { infection (D) }\end{array}$ & 33 & 32.7 & $32.7+/-7.4$ \\
\hline $\begin{array}{c}\text { Diabetics with bacterial } \\
\text { infection (DI) }\end{array}$ & 32 & 63.4 & $63.4+/-7.8$ \\
\hline \multicolumn{3}{|c|}{ Table 1. Results of NBT Measurement Based on the } \\
Classic System [NBT\%] \\
\hline
\end{tabular}

\begin{tabular}{|c|c|}
\hline Diagnosis & Isolated Organism [Number of Cases] \\
\hline Wound infection & $\begin{array}{l}\text { Klebsiella, }^{[4]} \text { Proteus, }{ }^{[4]} \text { Pseudomonas, }{ }^{[2]} \\
\text { Coagulase negative staphylococcus }{ }^{1]}\end{array}$ \\
\hline Abscess & Pseudomonas, ${ }^{[1]}$ E.coli ${ }^{[2]}$ \\
\hline Respiratory infection & Klebsiella, $^{[2]}$ Pseudomonas ${ }^{[1]}$ \\
\hline Ulcer foot & Pseudomonas, ${ }^{[1]}$ Klebsiella, ${ }^{[1]}$ E.coli[1] \\
\hline Urinary tract infection & E.coli, ${ }^{[1]}$ Acinetobacter ${ }^{[1]}$ \\
\hline Leptospirosis & Leptospira $^{[2]}$ \\
\hline Enteric fever & S.typhi[2] \\
\hline Fournier's gangrene & Pseudomonas ${ }^{[1]}$ \\
\hline Necrotizing fasciitis & Acinetobacter $[1]$ \\
\hline Meningoencephalitis & S.typhi[1] \\
\hline Septicaemia & Pseudomonas[1] \\
\hline Vaginitis & Staphylococcus aureus ${ }^{[1]}$ \\
\hline Total number of cases & 31 \\
\hline \multicolumn{2}{|c|}{$\begin{array}{l}\text { Table 2. Clinical Diagnosis and Organisms Isolated From } \\
\text { 'Non-DM with Infection (NDI) Category' }\end{array}$} \\
\hline
\end{tabular}

\begin{tabular}{|c|c|}
\hline Diagnosis & Isolated Organism [Number of Cases] \\
\hline Diabetic foot & $\begin{array}{c}\text { Proteus, }{ }^{[6]} \text { Pseudomonas, }{ }^{[2]} \text { Klebsiella, }{ }^{[4]} \text { Coagulase } \\
\text { negative staphylococcus }{ }^{[2]}\end{array}$ \\
\hline $\begin{array}{l}\text { Urinary tract } \\
\text { infection }\end{array}$ & $\begin{array}{c}\text { Pseudomonas, }{ }^{[1]} \text { E.coli, }{ }^{[6]} \text { Citrobacter, }{ }^{[1]} \text { Klebsiella, }^{[2]} \\
\text { Coagulase negative staphylococcus } \\
\end{array}$ \\
\hline Wound infection & Proteus $^{[2]}$ \\
\hline Melioidosis & B. pseudomallei ${ }^{[1]}$ \\
\hline Peritonitis & Coagulase negative staphylococcus ${ }^{[1]}$ \\
\hline Enteric fever & S.typhi ${ }^{[1]}$ \\
\hline Osteomyelitis & Staphylococcus aureus[1] \\
\hline Ulcer scrotum & Pseudomonas $^{[1]}$ \\
\hline $\begin{array}{c}\text { Total Number of } \\
\text { Cases }\end{array}$ & 32 \\
\hline \multicolumn{2}{|c|}{$\begin{array}{c}\text { Table 3. Clinical Diagnosis and Organisms Isolated from } \\
\text { 'Diabetes with Infection (DI) Category' }\end{array}$} \\
\hline
\end{tabular}

\begin{tabular}{|c|c|c|c|c|c|}
\hline & & \multicolumn{4}{|c|}{ Number \& [Proportion] of Cases } \\
\hline $\begin{array}{c}\text { Sl. } \\
\text { No. }\end{array}$ & NBT \% & ND [\%] & NDI [\%] & D [\%] & DI [\%] \\
\hline 1 & $0-20$ & $19[61.3 \%]$ & $0[0 \%]$ & $8[24.2 \%]$ & $1[3.1 \%]$ \\
\hline 2 & $21-40$ & $9[29 \%]$ & $2[6.4 \%]$ & $18[54.5 \%]$ & $6[18.8 \%]$ \\
\hline 3 & $41-60$ & $2[6.5 \%]$ & $4[12.9 \%]$ & $3[9.1 \%]$ & 8 [25\%] \\
\hline 4 & $61-80$ & $1[3.2 \%]$ & $11[35.5 \%]$ & $2[6.1 \%]$ & $6[18.7 \%]$ \\
\hline 5 & $81-100$ & $0[0 \%]$ & $14[45.2 \%]$ & $2[6.1 \%]$ & $11[34.4 \%]$ \\
\hline & & $31[100 \%]$ & $31[100 \%]$ & $33[100 \%]$ & $32[100 \%]$ \\
\hline \multicolumn{6}{|c|}{$\begin{array}{c}\text { Table 4. Number and Proportion of Cases in each NBT } \\
\text { \% Range [CS] }\end{array}$} \\
\hline
\end{tabular}




\begin{tabular}{|c|c|c|c|c|c|}
\hline & \multicolumn{5}{|c|}{ NBT } \\
\hline & \begin{tabular}{|} 
Mean \\
NBT \%
\end{tabular} & $\begin{array}{c}\sigma \\
\text { Standard } \\
\text { Deviation }\end{array}$ & $\begin{array}{c}\text { Standard } \\
\text { Error of } \\
\text { Difference } \\
\text { Between } 2 \\
\text { Means }\end{array}$ & $\begin{array}{c}\mathrm{Z} \\
\mathrm{Z} \\
\text { Score }\end{array}$ & \begin{tabular}{|c|}
$\mathbf{p}$ \\
Value
\end{tabular} \\
\hline $\begin{array}{l}\text { Non-diabetics without } \\
\text { infection (ND) }\end{array}$ & 21.8 & 14 & \multirow{2}{*}{4.0} & \multirow{2}{*}{13.495} & \multirow{2}{*}{$<0.05$} \\
\hline $\begin{array}{l}\text { Non-diabetics with } \\
\text { Infection (NDI) }\end{array}$ & 76.5 & 17.7 & & & \\
\hline \multicolumn{6}{|c|}{$\begin{array}{l}\text { Table 5. Comparison of NBT Values Between Non-Diabetic } \\
\text { Categories }\end{array}$} \\
\hline
\end{tabular}

\begin{tabular}{|c|c|c|c|c|c|}
\hline & \multicolumn{5}{|c|}{ NBT } \\
\hline & $\begin{array}{c}\text { Mean } \\
\text { NBT } \\
\%\end{array}$ & $\boldsymbol{\sigma}$ & $\begin{array}{c}\text { Standard Error of } \\
\text { Difference Between } \\
\text { 2 Means }\end{array}$ & $\begin{array}{c}\mathbf{Z} \\
\text { Score }\end{array}$ & $\begin{array}{c}\mathbf{p} \\
\text { Value }\end{array}$ \\
\hline $\begin{array}{c}\text { Diabetics } \\
\text { without } \\
\text { infection (D) }\end{array}$ & 32.7 & 20.9 & & & \\
\cline { 1 - 2 } $\begin{array}{c}\text { Diabetics with } \\
\text { infection (DI) }\end{array}$ & 63.4 & 21.8 & 5.3 & 5.792 & $<0.05$ \\
\hline \multicolumn{7}{|c|}{ Table 6. Comparison of NBT Values Between DM Categories } \\
\hline
\end{tabular}

\begin{tabular}{|c|c|c|c|c|c|}
\hline & & NBT & \\
\hline & $\begin{array}{c}\text { Mean } \\
\text { NBT \% }\end{array}$ & $\sigma$ & $\begin{array}{c}\text { Standard } \\
\text { Error of } \\
\text { Difference } \\
\text { Between 2 } \\
\text { Means }\end{array}$ & Z Z & p \\
Score & Value \\
\cline { 1 - 4 } $\begin{array}{c}\text { Non-diabetics without } \\
\text { infection (ND) }\end{array}$ & 21.8 & 14 & 4.4 & 2.465 & $<0.05$ \\
\hline $\begin{array}{c}\text { Diabetics without } \\
\text { infection (D) }\end{array}$ & 32.7 & 20.9 & & \\
\hline Table 7. Comparison of NBT Values Between ND and D Categories \\
\hline
\end{tabular}

\begin{tabular}{|c|c|c|c|c|c|}
\hline & \multicolumn{5}{|c|}{ NBT } \\
\hline & $\begin{array}{c}\text { Mean } \\
\text { NBT \% }\end{array}$ & $\sigma$ & $\begin{array}{c}\text { Standard } \\
\text { Error of } \\
\text { Difference } \\
\text { Between } 2 \\
\text { Means }\end{array}$ & $\begin{array}{c}Z \\
\text { Score }\end{array}$ & $\begin{array}{c}\mathbf{p} \\
\text { Value }\end{array}$ \\
\hline $\begin{array}{l}\text { Non-diabetics with } \\
\text { infection (NDI) }\end{array}$ & 76.5 & 17.7 & \multirow{2}{*}{4.9} & \multirow{2}{*}{2.622} & \multirow{2}{*}{$<0.05$} \\
\hline $\begin{array}{l}\text { Diabetics with infection } \\
\text { (DI) }\end{array}$ & 63.4 & 21.8 & & & \\
\hline Table 8. Compariso & $\begin{array}{r}n \text { of } N B T \\
\quad(N D\end{array}$ & & Subjec & & \\
\hline
\end{tabular}

\begin{tabular}{|c|c|c|c|c|}
\hline & $\begin{array}{c}\text { Non- } \\
\text { Diabetics } \\
\text { without } \\
\text { Infection } \\
\text { (ND) }\end{array}$ & $\begin{array}{c}\text { Non- } \\
\text { Diabetics } \\
\text { with } \\
\text { Infection } \\
\text { (NDI) }\end{array}$ & $\begin{array}{c}\text { Diabetics } \\
\text { without } \\
\text { Infection } \\
\text { (D) }\end{array}$ & $\begin{array}{c}\text { Diabetics } \\
\text { with } \\
\text { Infection } \\
\text { (DI) }\end{array}$ \\
\hline $\begin{array}{c}\text { Mean NBT } \\
\text { grading score } \\
\text { [maximum } \\
\text { score of 400] }\end{array}$ & 82 & 228.5 & 117.2 & 198.8 \\
\hline \multicolumn{3}{|c|}{ Table 9. Mean NBT Scores Based on Grading System [GS] } \\
\hline
\end{tabular}

\begin{tabular}{|c|c|c|c|c|c|}
\hline & & \multicolumn{4}{|c|}{ Percentage of Cases } \\
\hline S1. No. & $\begin{array}{l}\text { NBT Grading } \\
\text { Score Range }\end{array}$ & ND (\%) & NDI (\%) & D (\%) & DI (\%) \\
\hline 1 & $0-50$ & 39.3 & 3.3 & 0 & 0 \\
\hline 2 & $51-100$ & 25 & 3.3 & 45.5 & 0 \\
\hline 3 & $101-150$ & 25 & 6.7 & 33.3 & 32.3 \\
\hline 4 & $151-200$ & 10.7 & 16.7 & 12.1 & 22.6 \\
\hline 5 & $201-250$ & 0 & 30 & 6.1 & 22.6 \\
\hline 6 & $251-300$ & 0 & 26.7 & 3 & 16.1 \\
\hline 7 & $301-350$ & 0 & 13.3 & 0 & 6.4 \\
\hline 8 & $351-400$ & 0 & 0 & 0 & 0 \\
\hline \multicolumn{7}{|c|}{ Total \% } & 100 & 100 & 100 & 100 \\
\hline Table 10. Percentage of Case Distribution in Grading System \\
\hline
\end{tabular}

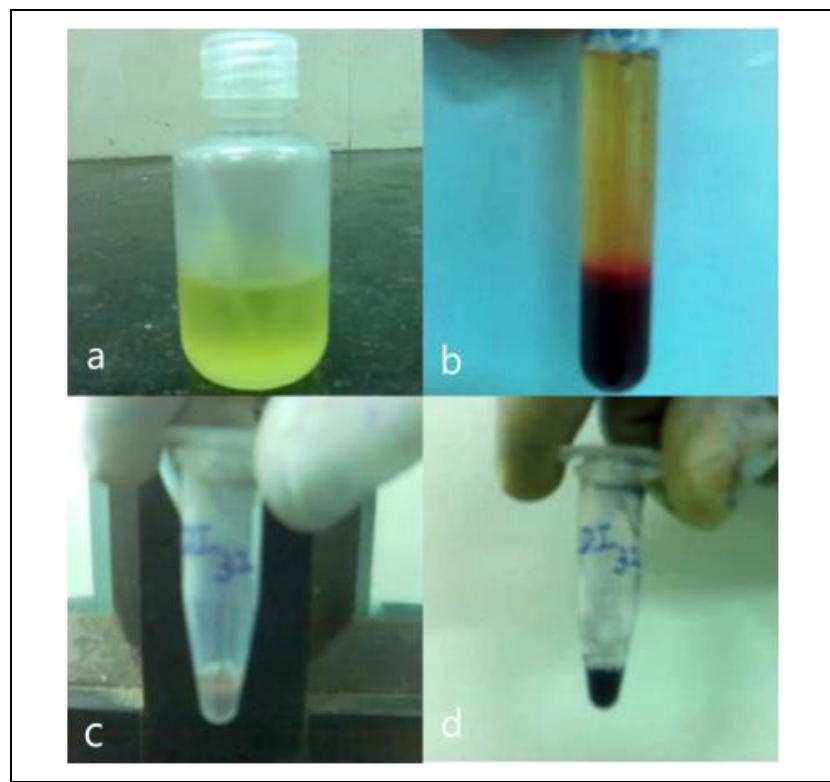

Figure 1. a] NBT Dye with Buffer Solution; b] Buffy Coat after Centrifuging; c] Buffy Coat with NBT-Buffer Prior to Incubation; d] Buffy Coat with NBT-Buffer Mixture after Incubation, Turning Blue
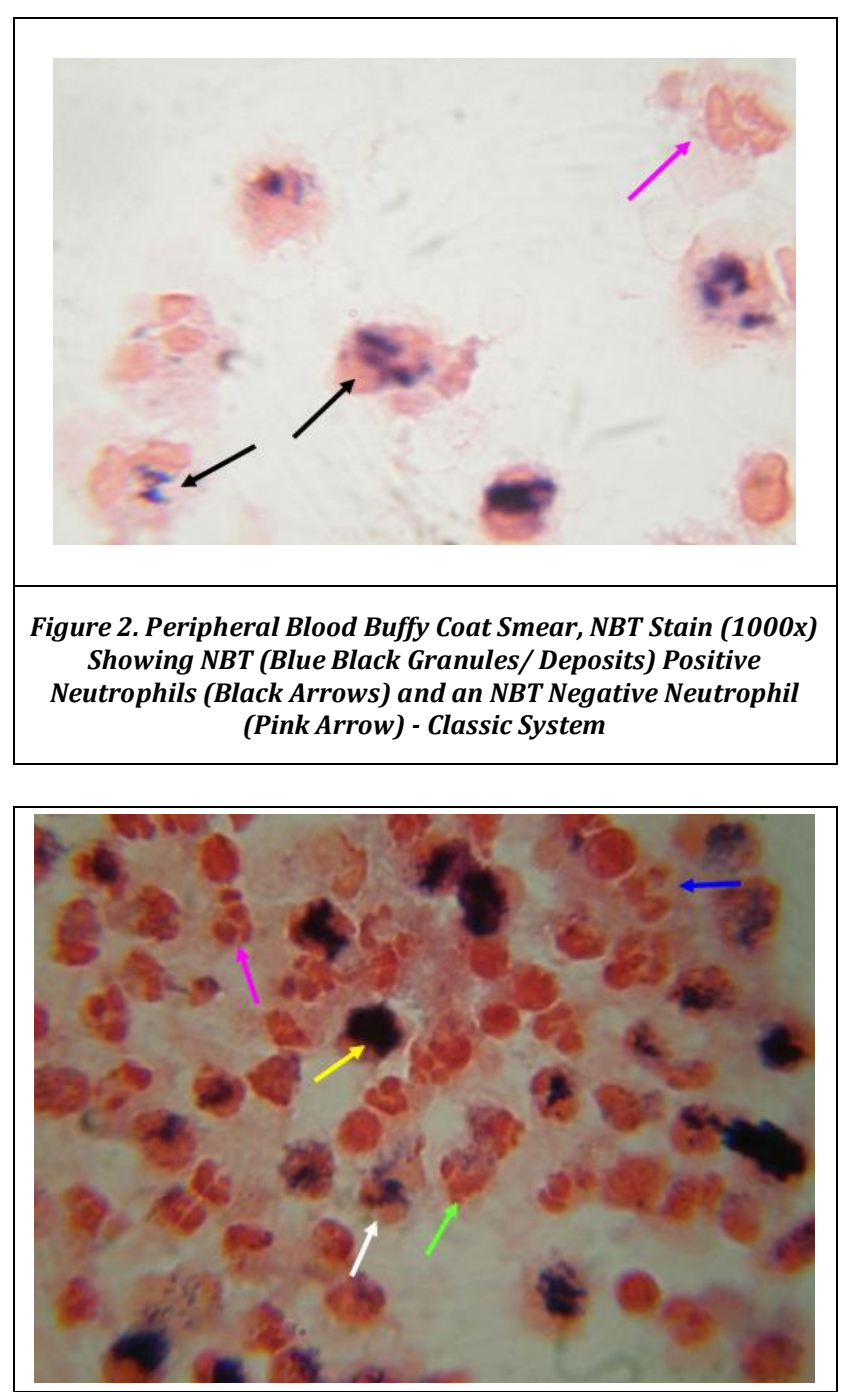

Figure 3. Peripheral Blood Buffy Coat Smear, NBT Stained (1000x) Neutrophils Showing the Grading System (Grade 0-Pink Arrow), (1-Blue Arrow) (2-Green Arrow) (3-White Arrow) and (4-Yellow Arrow) 


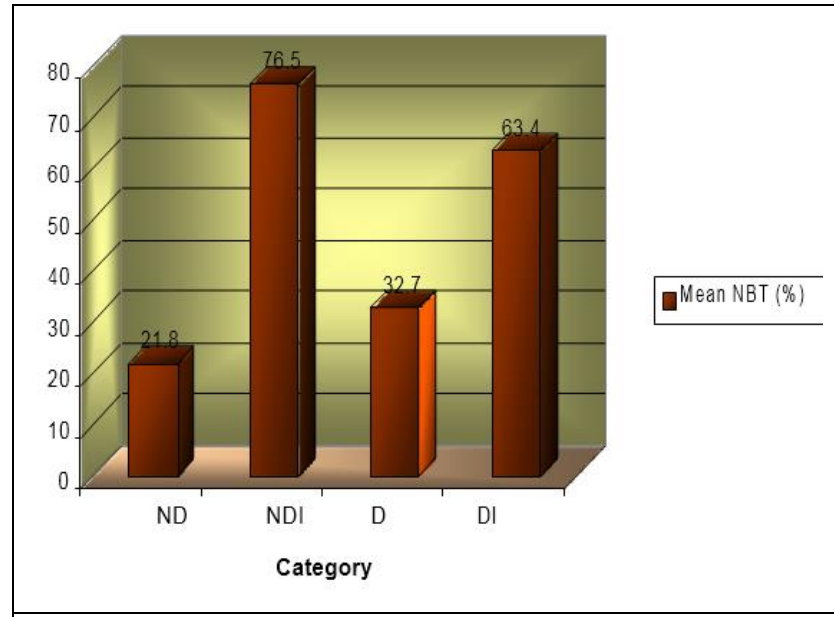

Figure 4. Mean NBT \% in all 4 Categories [Classic System]

NDI category included 31 patients [24 males +7 females] who had a clinically and microbiologically proved bacterial infection [Table 2] with their age ranging from 19 to 75 years. The mean NBT value in males was $76.9 \%$ and females was $75.1 \%$ with no significant difference between the sexes ( $p>0.05)$.

33 DM patients without infection (D) were selected of whom 16 were males and 17 were females in the age range of 27 to 78 years. The mean NBT value of the males was $26.06 \%$ and females was $39 \%$ with no significant difference $(p>0.05)$ between them. 24 cases had FBS $<200 \mathrm{mg} / \mathrm{dl}$ whereas the rest had higher FBS levels.

DI category of 32 patients [19 males, 17 females], had age ranging from 20 to 85 years. The diagnoses and organisms isolated are given in table 3 . The mean NBT value of the males was $59 \%$ and not significantly lower than that of females (mean NBT\%=69.8\%).

\section{DISCUSSION}

We studied the distribution of cases in different NBT value ranges, and observed (Table 4 ) that $90.3 \%$ of ND, and $78.7 \%$ of D categories had NBT values less than 40 , however in D category, most cases [54.5\% cases] had NBT \% between 20 and 40 , indicating persistent activation. And it was evident that among those with infection (Table 4), 80.7\% of nondiabetics (NDI) had NBT values above 60 compared to only $53.1 \%$ by diabetics (DI), suggesting that DM patients were unable to activate their neutrophils as much as non-DM patients.

The significantly higher NBT values in NDI category compared to ND category, obtained in our study [Table 5] was similar to that of various standard studies like Gordon et al ${ }^{23}$ who had mean NBT value of $60 \%$ and $18 \%$ for NDI and ND categories, while Trojan et al11 had NBT values of $72 \%$ (NDI) and $33 \%$ (ND).

But some studies showed lower overall NBT values, for example Yun Woong Ko et $\mathrm{al}^{24}$ who had NBT values of $3.2 \%(\mathrm{ND})$ and $10.6 \%(\mathrm{NDI})$ respectively, which might be due to differences in procedure and sample size. With reference to counting techniques, some studies ${ }^{5}$ considered only those cells exhibiting a discrete particulate (Coarse) cytoplasmic distribution of formazan along with those showing dense deposits of formazan (Block positivity) as positive cells whereas in our study both fine \& coarse granules and dense deposits were taken as positive.
In diabetics, the mean NBT values of those with infection (DI) were significantly higher than those without (D), which is displayed in table 6. Yun Woong Ko et al24 in 1977 had a similarly raised NBT values in DI category [Mean NBT 4.6\%] compared to category D [Mean NBT 2.6\%].

This rise in NBT values seen in the presence of infection [with or without diabetes] in our study, as with others, was in accordance to the fact that neutrophils, on stimulation by an infectious pathogen, have an increased bactericidal activity. ${ }^{12}$ As shown above [Table 7], in those without infection, the mean NBT \% of D category was significantly higher $(\mathrm{p}<0.05)$ than that of ND. Our results compared well with those of Kruszewski et al ${ }^{19}$ in 1979 , Lechowski et $\mathrm{al}^{25}$ in 1991 and Larijani et $\mathrm{al}^{20}$ in 2007 but not with Yun Woong Ko et al ${ }^{24}$ which might be due to a small sample size. The higher mean NBT value in D category compared to the ND category could be related to the persistent activated state of neutrophils seen in diabetics due to AGEs. ${ }^{18}$ Nuran Nabi et $\mathrm{al}^{26}$ in 2005, also found that diabetic rats showed higher NBT values compared to control healthy rats $(\mathrm{p}<0.001)$ which was comparable to other neutrophil function tests like polarization assay where the neutrophils of diabetic rats were more polarized at baseline level compared to control rats.

The mean NBT values of diabetics with infection (63.4\%) was significantly lower than that of non-diabetics with infection (76.5\%) [Table 8]. Our results were in concurrence with the study by Larijani et al 20 in 2007, which compared 19 diabetic foot patients with 20 controls. The mean NBT values of the non-infected diabetics in their study was significantly higher compared to controls, whereas stimulated NBT test showed an inadequate rise in diabetics but a marked rise in controls.

It could probably be related to the fact that the persistent hyper-excited state of neutrophils in diabetics leads to "burn out' of neutrophils which respond inadequately when stimulated by an infectious pathogen. This burnt out state had been demonstrated by Shah et al,27 who showed reduced superoxide radical production by neutrophils of diabetics on exposure to infecting pathogen. The production of superoxide and other free radicals require NADPH-oxidase which is also essential for NBT reduction. Hence the constant state of activation of neutrophils in resting state in diabetics could probably also result in loss of enzymes necessary for oxygen derived free radical production, which when subsequently stimulated by infectious pathogens, leads to an inadequate functional response (lower NBT values). ${ }^{20}$

Binding of advanced glycation end products (AGEs) to lysosomal enzymes as was demonstrated by Li.Y.M17 could also play a role in the reduced elevation of respiratory burst.

The mean NBT scores by GS [Table 9], were proportional to that of the classic system [Table 1], with the analysis generating equivalent comparisons [i.e., NDI $>$ ND, DI> D, $\mathrm{D}>\mathrm{ND}$, and NDI $>\mathrm{DI}$ respectively].

Among the non-infected, all (100\%) cases of category ND and $90.9 \%$ of category D had NBT grading score less than 200 (Table 10) and this was comparable to the NBT \% of positive cells given by Classic System [Table 4]. We found GS to be more sensitive than CS in individual cases to pick up the low grade activated state of neutrophils in DM without infection, because on further scrutinizing, though D category had $90.9 \%$ cases with less than 200 grading score, there were no cases with less than 50 score.

Among the infected, the NBT grading score (Table 10) was above 200 in $70 \%$ non-DM but only in $45.1 \%$ of DM cases while the same was between $100-200$ in $54.9 \%$ of DM but only 
$23.4 \%$ of non-DM further reinstating that neutrophils in DM patients get fired up even without infection, and unable to mount a higher response when stimulated by infection.

\section{CONCLUSIONS}

This study attempted to analyze the bactericidal function of the neutrophils by the simple NBT test in diabetes mellitus. The classical system (based on the presence or absence of formazan granules in cytoplasm) and NBT grading system were employed and the study population included nondiabetics without infection, non-diabetics with infection, diabetics without infection and diabetics with infection [Figure 4]. Higher NBT values [both CS \& GS] were observed in diabetics [without infection] when compared to non-diabetics without infection. It could probably have been a result of persistent activation of resting neutrophils in diabetics. Irrespective of the diabetic status, patients when exposed to infectious agents [NDI \& DI], had higher mean NBT \% \& grade, thereby confirming NBT test as a useful test to ascertain the presence of infection as well as reflecting a neutrophil functional response [neutrophil activation leads to NADPH oxidase activation which results in higher NBT \% \& grade]. However, the mean NBT \% \& grade of diabetics with infection did not reach the higher mean NBT values of non-diabetics with infection, probably related to the hyper-excited state of resting neutrophils, leading to burn out and reduced ability of neutrophils to mount a high respiratory burst activity (defective bactericidal function). No correlation was found between NBT \% and gender in our study. Both classic \& grading systems showed parallel results, while GS was more sensitive in picking up the low-grade activation of neutrophils in individual cases of DM without infection. Pitfalls in our study were that the degree of control of diabetes mellitus (HbA1c) was not evaluated and that serial evaluation of subjects had not been done. Future studies can include the relationship between degree of control of DM/ HbA1c levels and NBT \% \& grade; the feasibility of NBT measurement as a screening test of neutrophil function and its predictive value in response to infections; comparison of NBT \% \& grade to other tests of neutrophil function; incorporating grading in routine NBT tests to effect a standardized evaluation and thereby reducing variation observed in the classical system between different studies; and conducting NBT tests on a larger sample size.

\section{ACKNOWLEDGEMENTS}

We thank MMC for study subjects \& medical records, Institute of Pathology [MMC] for the technical support, Dr. M. P. Kanchana for encouragement, Dr. S. Chitrakala \& Dr. K. Aruna for assistance in data collection and Dr. S. Y. Jagannathan for advice on statistics.

\section{REFERENCES}

[1] Kaushansky K, Lichtman MA, Prchal JT, et al. William's Hematology. $9^{\text {th }}$ edn. New York: McGraw-Hill Education 2015.

[2] Weerasinghe A. Investigating an immunecompromised child. Sri Lanka Journal of Child Health 2000;29(4):116-9.
[3] Murray RK. Red \& White blood cells. In: Murray RK, Bender DA, Botham KM, et al. eds. Harper's Illustrated Biochemistry. 28 $8^{\text {th }}$ edn. New York: McGraw-Hill Publication 2009: p. 604-6.

[4] Kumar V, Abbas AK, Aster JC. Robbins \& Cotran Pathologic basis of disease. South Asian edn. Amsterdam: Elsevier 2014: p. 78-80.

[5] Gordon AM, Rowan RM, Brown T, et al. Routine application of the nitroblue tetrazolium test in the clinical laboratory. J Clinical Path 1973;26(1):52-6.

[6] Baehner RL, Nathan DG. Leukocyte oxidase: defective activity in chronic granulomatous disease. Science 1967;155(3764):835-6.

[7] Park BH, Fikrig SM, Smithwick EM. Infection and nitroblue tetrazolium reduction by neutrophils. A diagnostic aid. Lancet 1968;2(7567):532-4.

[8] Feigin RD, Shakelford PG, Choi SC, et al. Nitroblue tetrazolium test as an aid in the differential diagnosis of febrile disorders. J Pediatr 1971;78(2):230-7.

[9] Anderson BR. N.B.T test in malaria. Lancet 1971;298(7719):317.

[10] Humbert JR, Kurtz ML, Hathaway WE. Increased reduction of nitroblue tetrazolium by neutrophils of newborn infants. Pediatrics 1970;45(1):125-8.

[11] Trojan I, Weippl G. The nitroblue tetrazolium test in scarlet fever. Wein Klin Wochenschr 1975;87(8):270-2.

[12] McCall CE, DeChatelet LR, Butler R, et al. Enhanced phagocytic capacity. The biologic basis for the elevated histochemical nitroblue tetrazolium reaction. J Clin Invest 1974;54(5):1227-34.

[13] Cockram CS, Lee N. Diabetes and Infections. In: Holt RIG, Cockram CS, Flyvbjerg A, Goldstein BJ, editors. Textbook of Diabetes. 4th edition. New Jersey:WileyBlackwell 2010.p.835- 837.

[14] Brayton RG, Stokes PE, Schwartz MS, et al. Effect of alcohol and various diseases on leukocyte mobilization, phagocytosis and intracellular bacterial killing. $\mathrm{N}$ Engl J Med 1970;282(3):123-8.

[15] Delamaire M, Maugendre D, Moreno M, et al. Impaired leucocyte function in diabetic patients. Diabet Med 1997;14(1):29-34.

[16] Gallacher SJ, Thomson G, Fraser WD, et al. Neutrophil bactericidal function in diabetes mellitus: evidence for association with blood glucose control. Diabet Med 1995;12(10):916-20.

[17] Li YM. Glycation ligand binding motif in lactoferrin. Implications in diabetic infection. Adv Exp Med Biol 1998;443:57-63.

[18] Calvet HM, Yoshikawa TT. Infections in diabetes. Infect Dis Clin North Am 2001;15(2):407-21, viii.

[19] Kruszewski J, Markiewicz K, Koczorowski T. Value of the test of spontaneous reduction of nitroblue tetrazolium in diabetes decompensation. Med Interne 1979;17(2):197-9.

[20] Larijani B, Shooshtarizadeh P, Mosaffa N, et al. Polymorphonuclear leucocyte respiratory burst activity correlates with serum zinc level in type 2 diabetic patients with foot ulcers. Br J Biomed Sci 2007;64(1):13-7. 
[21] Kasper DL, Braunwald E, Hauser S, et al. Harrison's Principles of Internal Medicine. 16 ${ }^{\text {th }}$ edn. New York: McGraw-Hill Professional 2004.

[22] Swirsky D, Bain BJ. Erythrocyte and leucocyte cytochemistry. In: Bain BJ, Bates I, Lewis M, eds. Dacie and Lewis Practical Haematology. 10th edn. London: Churchill Livingstone 2006: p. 320.

[23] Gordon PA, Stuart J, Lee TR, et al. The cytocentrifuge NBT test. J Clin Pathol 1975;28(8):674-9.

[24] Ko YW, Hahn JS, Paek CY, et al. NBT and stimulated NBT test in patients with diabetes mellitus. Korean J Hematol 1977;12(2):107-15.
[25] Lechowski R, Lenarcik M, Degorski A, et al. Serum lysozyme activity and nitroblue tetrazolium reduction test in dogs with diabetes mellitus. Zentralbl Veterinarmed A 1991;38(7):530-3.

[26] Nabi AH, Islam LN, Rahman MM, et al. Polymorphonuclear neutrophil dysfunctions in streptozocin-induced type 1 diabetic rats. J Biochem Mol Biol 2005;38(6):661-7.

[27] Shah SV, Wallin JD, Eilen SD. Chemiluminescence and superoxide anion production by leucocytes from diabetic patients. J Clin Endocrinol Metab 1983;57(2):402-9. 